\title{
Effects of some probiotics during its use as a growth promoter in calves
}

Magdy S. Amer, Mohamed G. Elsayed And Dina M.Elallamy

Pharmacology Department - Faculty Vet-Med. Mansoura University

ABSTRACT

\begin{abstract}
This study was performed on to evaluate the effect of some probiotic strains (Pediococcus acidophilus and Pedicoccus pentosaceus) on performance, blood picture and some biochemical parameters in serum of treated calves (10 weaned calves $90-115 \mathrm{~kg}$ ). Calves were classified into 2 equal groups (each of 5 calves). The 1 st group was served as the control group while the second group was given Maxboost ${ }^{\circledR}(20 \mathrm{gm} / \mathrm{head} /$ day $)$ in drinking water (after fermentation for 2-3 hours) for five months. Calves were weighed monthly to calculate the body weight gain till the end of the experiment whole blood weight and serum were collected from both groups at 1st, 2nd, 3rd, 4th and 5th month. Results revealed a significant increase in total body weight, body gain, total erythrocytes count, hemoglobin content, total leucocytes count, total protein and mean corpuscular hemoglobin. On the other hand, there were a significant decrease in serum aspartate transaminase (AST), serum alanine transaminase (ALT) and urea in pediococcus treated group compared to the control one.
\end{abstract}

\section{INTRODUCTION}

Probiotics as growth promoter are a culture (either mono or mixed) of living microorganisms. They produce a beneficial effect on the host by improving the properties of the indigenous micro- flora (Ghadban, G., 2002. Good features of good probiotic must be a strain, which is capable of exerting a beneficial effect on animals, by increasing the performance. Also it should be non-pathogenic, non-toxic, and capable of surviving and metabolizing in gut environment and should be capable of remaining viable for periods under storage and field conditions (Fuller, 1989).

The alimentary bacterial probiotics play an important role in improving the general health conditions of the animals (Fuller, 1992). Such beneficial effects of the probiotic depending many factors as the chosen strain, duration and frequency of exposure, and the physiological status of the animal. (Koop-Hoolihan, 2001).

Probiotics have several beneficial effects on the host animal such as: increasing milk yield, fat and protein contents (Yu et al, 1997), growth promotion (Change et al, 2001), synthesis off nutrients as vitamin B complex and amino acids (Koop-Hoolihan,2001), immunostimulant by increasing phagocyte activity and immunoglobulin levels (Aattor et al,2002), production of the animal from the intestinal infection (Oyetayo et al.,2003), increasing the carcass output and output and water holding capacity and decreasing the meat hardness (Ceslovas et al.,2005) and reducing morbidity and mortality of the growing animals (Paulius et al.,2006).
The available probiotics mainly belong to the genera Lactobacillus and Bifidobacterium. Pediococcus is a Grampositive LAB of the family Lactobacillaceae. The genus Pediococcus is comprised of $P$. acidilactici, P. pentosaceus, $P$. damnosus, $P$. parvulus, $P$. inopinatus, $P$. halophilus, $P$. dextrinicus and $P$. urinaeequi (Garvie 1986).

This work aimed to study the effects of the used preparation as a growth promoter on performance, hemogram and some biochemical parameters of treated calves.

\section{MATERIALS AND METHODS}

3-Drug and chemical composition

- (Maxboost $\left.{ }^{\circledR}\right)$

- Pediococcus acidilactici $\quad 1 \times 106 \mathrm{cfu} / \mathrm{g}$

- Pediococcus pentosaceus $\quad 1.3 \times 106 \mathrm{cfu} / \mathrm{g}$

- Dextrose as carrier.

Manufactured \& explored by DVS Biolife limited - India purchase Experimental animals and grouping:

Ten apparently healthy male cow calves of cross breed (5-6 months of age ) With average body weight 90-115 kg. They were reared in special farm in Dakahlia Governorate and fed on concentrated ration of $18 \%$ protein (by $1 \%$ of body weight) and water was provided ad-libitum.

Calves were classified into 2 equal groups, each of 5 calves as the following:

G1: control group (without treatment)

G2: calves given pediococcus mix at $20 \mathrm{gm} /$ head/day for 5 months. Body weight was determined in the beginning of the experiment and monthly, moreover the general health conditions were observed. 4-Sampling 
Two blood samples (the first was collected on heparinized test tubes used for hematological studies and the second was collected into a Temperature for 45 minute) were collected from each animal at zero day, $1^{\text {st }}, 2^{\text {nd }}, 3^{\text {rd }}, 4^{\text {th }}$ and $5^{\text {th }}$ month after drug administration.

5. Hematological studies:

Were carried out using fully automated cell counter R.B.Cs, W.B.Cs count, $\mathrm{Hb}$ concentration, PCV\% and blood platelets were determined according to Colos (1986).

6. Serum Biochemical Analysis:

(A) Liver function tests:

- Determination of Total Protein level according to Doumas, (1975)

- Determination of Albumin level according to Doumas, (1975) dry sterile centrifuge tube and allowed to clot at room

- Serum globulin calculation as described by Doumas and Biggs, (1972)

- Determination of serum Transaminases (ALT) and (AST) activities according to Reitman and Frankel, (1957).

- Determination of serum Alkaline phosphatase (ALP) activity according to Rosalki, (1993).

(B) Kidney function tests:

- Determination of serum Creatinine: according to (Henry, 1974)

- Determination of Urea: according to (Patton and Crouch, 1977)

Statistical analysis: as described by Snedecor and Cohoran, (1981)

\section{RESULTS}

Ten calves at Dakahlia governorate were observed and weighted for five months to evaluate the body performance as mentioned in Table (1).

Table(1): The effect of oral administration of Pedicoccus $\left(23 \times 10^{6} \mathrm{CFU} /\right.$ calf/day) in ration once daily for five months on body weight, body gain, food intake and food conversion rate in cow calves. (Mean \pm S.E) $\quad(n=5)$

\begin{tabular}{|c|c|c|c|c|c|c|c|}
\hline Item & Group & Zero & $1^{\mathrm{st}}$ & $2^{\text {nd }}$ & $3^{\text {rd }}$ & $4^{\text {th }}$ & $5^{\text {th }}$ \\
\hline \multirow[t]{2}{*}{ Body weight (kg) } & Control & $100 \pm 6.52$ & $117.8 \pm 6.46$ & $138 \pm 3.82$ & $150.6 \pm 3.59$ & $172.8 \pm 1.32$ & $209.4 \pm 2.58$ \\
\hline & Treated & $100.6 \pm 3.79$ & $125.2 \pm 3.97$ & $152 \pm 3.35 *$ & $177.6 \pm 2.7 *$ & $209.6 \pm 3.04 *$ & $244.8 \pm 6.15 *$ \\
\hline \multirow[t]{2}{*}{ Body gain (kg) } & Control & $17.8 \pm 1.8$ & $20.2 \pm 3.47$ & $12.6 \pm 1.63$ & $22.2 \pm 3.24$ & $36.6 \pm 3.65$ & $109.4 \pm 8.58$ \\
\hline & Treated & $24.6 \pm 1.96 *$ & $26.8 \pm 2.13 *$ & $25.6 \pm 3.23 *$ & $32 \pm 2.24 *$ & $34.8 \pm 3.34$ & $144.2 \pm 8.5 *$ \\
\hline \multirow[t]{2}{*}{ Feed intake $(\mathrm{kg})$} & Control & $1.88 \pm .014$ & $2.36 \pm 0.13$ & $2.76 \pm 0.07$ & $3.01 \pm 0.07$ & $3.46 \pm 0.02$ & $4.19 \pm 0.05$ \\
\hline & Treated & $1.95 \pm 0.06$ & $2.5 \pm 0.07$ & $3.04 \pm 0.06$ & $3.55 \pm 0.05$ & $4.19 \pm 0.06$ & $4.89 \pm 0.12$ \\
\hline \multirow[t]{2}{*}{ Conversion rate } & Control & $3.32 \pm 0.49$ & $3.96 \pm 0.72$ & $6.95 \pm 0.79$ & $4.48 \pm 0.74$ & $2.95 \pm 0.35$ & $5.06 \pm 0.56$ \\
\hline & Treated & $2.42 \pm 0.18$ & $2.87 \pm 0.26$ & $3.47 \pm 0.39$ & $3.51 \pm 0.27$ & $3.75 \pm 0.38$ & $4.25 \pm 0.27$ \\
\hline
\end{tabular}


Table (2): The effect of oral administration of Pedicoccus $\left(23 \times 10^{6} \mathrm{CFU} /\right.$ calf/day) in ration once daily for five months on total erythrocytes count, hemoglobin content and packed cell volume (PCV), $\mathrm{MCV}, \mathrm{MCH}, \mathrm{MCHC}$ and total and differential leucocytes count in cow calves .

$($ Mean \pm S.E) .

\begin{tabular}{|c|c|c|c|c|c|c|c|}
\hline Item & Group & Zero & $1^{\mathrm{st}}$ & $2^{\text {nd }}$ & $3^{\mathrm{rd}}$ & $4^{\text {th }}$ & $5^{\text {th }}$ \\
\hline \multirow[t]{2}{*}{$\operatorname{RBCs}\left(\mathrm{n} \times 10^{6} / \mathrm{ML}\right)$} & Control & $6.57 \pm 0.31$ & $6.46 \pm 0.20$ & $5.98 \pm 0.07$ & $6.04 \pm 0.12$ & $5.64 \pm .014$ & $5.56 \pm 0.33$ \\
\hline & Treated & $6.77 \pm 0.32$ & $7.46 \pm 0.22 *$ & $7.4 \pm 0.18 *$ & $7.64 \pm 0.22 *$ & $7.36 \pm 0.43 *$ & $7.52 \pm .047 *$ \\
\hline \multirow[t]{2}{*}{ HB (gm./dl) } & Control & $8.6 \pm 0.41$ & $7.4 \pm 0.4$ & $7.4 \pm 0.51$ & $7.4 \pm 0.68$ & $6.6 \pm 0.51$ & $7.4 \pm .0 .24$ \\
\hline & Treated & $8.58 \pm 0.29$ & $10.6 \pm 0.51^{*}$ & $11 \pm 0.45^{*}$ & $11.6 \pm 0.68^{*}$ & $10.6 \pm 0.24 *$ & $11 \pm 0.32 *$ \\
\hline \multirow[t]{2}{*}{ PCV (\%) } & Control & $24.08 \pm 0.87$ & $45.2 \pm 2.24$ & $34.4 \pm 3.68$ & $43.8 \pm 3.73$ & $38.8 \pm 0.66$ & $37.7 \pm 2.1$ \\
\hline & Treated & $25.02 \pm 0.54$ & $\begin{array}{l}37.1 \pm 2.23 \\
* \downarrow\end{array}$ & $\begin{array}{l}38.1 \pm 2.58 \\
* \uparrow\end{array}$ & $41.26 \pm 3.69$ & $38.74 \pm 3.68$ & $37.78 \pm 3.73$ \\
\hline \multirow[t]{2}{*}{ MCV (fl) } & Control & $36.82 \pm 0.59$ & $36.54 \pm 0.5$ & $36.18 \pm 0.28$ & $36.04 \pm 0.15$ & $35.9 \pm 0.32$ & $36.12 \pm 0.54$ \\
\hline & Treated & $35.92 \pm 0.52$ & $35.78 \pm 0.33$ & $35.92 \pm 0.22$ & $35.9 \pm 0.23$ & $35.8 \pm 0.27$ & $35.78 \pm 0.41$ \\
\hline \multirow[t]{2}{*}{$\mathrm{MCH}(p g)$} & Control & $13.02 \pm 0.11$ & $8.6 \pm 0.4$ & $8.4 \pm 0.24$ & $7.8 \pm 0.49$ & $8.4 \pm 1.86$ & $11.9 \pm 0.46$ \\
\hline & Treated & $12.94 \pm 0.34$ & $12.2 \pm 1.22 *$ & $11.44 \pm 0.53 *$ & $11.38 \pm 1.16 *$ & $10.3 \pm 0.80 *$ & $11.94 \pm 0.52$ \\
\hline \multirow[t]{3}{*}{$\mathrm{MCHC}(\%)$} & Control & $35.6 \pm 0.61$ & $32.2 \pm 1.16$ & $32.2 \pm 0.86$ & $30.6 \pm 0.93$ & $31 \pm 0.55$ & $34.2 \pm 0.73$ \\
\hline & Treated & & & & & & \\
\hline & & $36.14 \pm 0.64$ & $33.2 \pm 1.32$ & $32.6 \pm 1.29$ & $24.64 \pm 4.30$ & $33.06 \pm 1.13$ & $33.24 \pm 1.18$ \\
\hline \multirow[t]{2}{*}{ WBCs $\left(\mathrm{n} \times 10^{3} / \mathrm{ml}\right)$} & Control & $11.05 \pm 0.61$ & $11.4 \pm 0.51$ & $8.6 \pm 0.4$ & $8.2 \pm 0.37$ & $8.2 \pm 0.37$ & $7.8 \pm 0.37$ \\
\hline & Treated & $10.97 \pm 0.55$ & $11.8 \pm 0.2$ & $11.6 \pm 0.24 *$ & $12.6 \pm 0.75 *$ & $13 \pm 0.45 *$ & $12 \pm 0.55 *$ \\
\hline \multirow[t]{2}{*}{ Neutrophil \% } & Control & $35.72 \pm 0.81$ & $35.6 \pm 0.68$ & $37.2 \pm 0.73$ & $36.4 \pm 0.75$ & $38 \pm 1.14$ & $35.8 \pm 1.60$ \\
\hline & Treated & $35.18 \pm 0.58$ & $35.8 \pm 0.2$ & $41.8 \pm 1.9 *$ & $44.2 \pm 1.8 *$ & $53 \pm 2.55 *$ & $44.2 \pm 1.16 *$ \\
\hline \multirow[t]{2}{*}{ Lymphocyte \% } & Control & $42.77 \pm 1.53$ & $41.2 \pm 0.37$ & $40.8 \pm 0.37$ & $42 \pm 0.45$ & $45.4 \pm 2.30$ & $49.6 \pm 2.7$ \\
\hline & Treated & $53.2 \pm 1.94 *$ & $52.2 \pm 0.58 *$ & $52.8 \pm 0.8 *$ & $51.4 \pm 0.51 *$ & $51.2 \pm 3.88 *$ & $48 \pm 7.91$ \\
\hline \multirow[t]{2}{*}{ Basophil \% } & Control & $0.25 \pm 0.11$ & $0.6 \pm 0.24$ & $0.2 \pm 0.2$ & $0.0 \pm 0.0$ & $0.2 \pm 0.2$ & $0.6 \pm 0.24$ \\
\hline & Treated & $0.30 \pm 0.08$ & $2.2 \pm 0.58$ & $0.0 \pm 0.0$ & $0.8 \pm 0.49$ & $0.0 \pm 0.0$ & $0.6 \pm 0.24$ \\
\hline \multirow[t]{2}{*}{ Eosinophil \% } & Control & $0.2 \pm 0.2$ & $0.0 \pm 0.0$ & $0.8 \pm 0.2$ & $0.6 \pm 0.4$ & $0.2 \pm 0.2$ & $0.2 \pm 0.2$ \\
\hline & Treated & $0.57 \pm 0.04$ & $2.2 \pm 0.37$ & $0.6 \pm 0.24$ & $0.8 \pm 0.37$ & $0.2 \pm 0.2$ & $0.8 \pm 0.37$ \\
\hline \multirow[t]{2}{*}{ Monocyte \% } & Control & $0.29 \pm 0.09$ & $1.8 \pm 0.49$ & $2 \pm 0.0$ & $2.4 \pm 0.24$ & $2.4 \pm 0.51$ & $3.8 \pm 0.58$ \\
\hline & Treated & $0.5 \pm 0.03$ & $1.8 \pm 0.58$ & $3 \pm 0.32 *$ & $4.2 \pm 0.58 *$ & $4 \pm 0.55 *$ & $4.2 \pm 0.58$ \\
\hline \multirow[t]{2}{*}{$\begin{array}{l}\text { Platelets } \\
/ \mathrm{ml} \text { ) }\end{array}$} & Control & $270.2 \pm 21.38$ & $352.8 \pm 7.7$ & $344.6 \pm 9.80$ & $362.2 \pm 5.6$ & $338 \pm 6.27$ & $560.4 \pm 23.5$ \\
\hline & Treated & $262.8 \pm 21.16$ & $390 \pm 17.85$ & $520.6 \pm 13.66$ & $451.4 \pm 1.3$ & $547.4 \pm 4.2$ & $559.6 \pm 25.21$ \\
\hline
\end{tabular}


Table (3): The effect of oral administration of Pedicoccus $\left(23 \times 10^{6} \mathrm{U} /\right.$ calf/day $)$ in ration once daily for five months on total protein, albumin, globulin, spartate transaminase (AST), alanine transaminase (ALT) and alkaline phosphatase (ALP), urea and creatinine in cow calves .

$($ Mean \pm S.E) .

\begin{tabular}{|c|c|c|c|c|c|c|c|}
\hline Item & Group & Zero & $1^{\mathrm{st}}$ & $2^{\text {nd }}$ & $3^{\text {rd }}$ & $4^{\text {th }}$ & $5^{\text {th }}$ \\
\hline \multirow[t]{2}{*}{ TP (g/dl) } & Control & $6.7 \pm 0.17$ & $5.76 \pm 0.24$ & $6.24 \pm 0.24$ & $5.1 \pm 0.25$ & $5.24 \pm 0.21$ & $6.74 \pm 0.18$ \\
\hline & Treated & $6.84 \pm 0.16$ & $7.74 \pm 0.50 *$ & $6.4 \pm 0.24$ & $6.9 \pm 0.16 *$ & $7.1 \pm 0.12 *$ & $6.9 \pm 0.2$ \\
\hline \multirow[t]{2}{*}{$\operatorname{ALB}(\mathrm{g} / \mathrm{dl})$} & Control & $3.15 \pm 0.10$ & $2.86 \pm 0.21$ & $2.76 \pm 0.16$ & $2.84 \pm 0.28$ & $3.36 \pm 0.25$ & $2.92 \pm 0.15$ \\
\hline & Treated & $3.26 \pm 0.05$ & $2.74 \pm 0.17$ & $\begin{array}{l}3.24 \pm 0.21 \\
*\end{array}$ & $2.92 \pm 0.32$ & $3.36 \pm 0.34$ & $3.24 \pm 0.14$ \\
\hline \multirow[t]{2}{*}{ globulin (g/dl) } & Control & $3.57 \pm 0.08$ & $2.9 \pm 0.36$ & $3.48 \pm 0.32$ & $2.26 \pm 0.44$ & $1.88 \pm 0.42$ & $3.66 \pm 0.12$ \\
\hline & Treated & $3.59 \pm 0.12$ & $5 \pm 0.44 *$ & $3.12 \pm 0.36$ & $\begin{array}{l}3.98 \pm 0.28 \\
*\end{array}$ & $3.74 \pm 0.15 *$ & $3.66 \pm 0.11$ \\
\hline \multirow[t]{2}{*}{ ALT (IU/L) } & Control & $26.6 \pm 5.03$ & $30.8 \pm 1.53$ & $31 \pm 2.66$ & $33.2 \pm 4.72$ & $32.4 \pm 3.14$ & $17.2 \pm 2.13$ \\
\hline & Treated & $29 \pm 1.87$ & $27 \pm 2.11$ & $\begin{array}{l}17.8 \pm 1.59 \\
*\end{array}$ & $18.6 \pm 1.6 *$ & $20.2 \pm 2.00 *$ & $19.4 \pm 2.2 *$ \\
\hline \multirow[t]{2}{*}{ AST (IU/L) } & Control & $171.6 \pm 7.2$ & $181.4 \pm 11.40$ & $173 \pm 8.46$ & $\begin{array}{l}166.6 \quad \pm \\
6.66\end{array}$ & $176 \pm 8.38$ & $150 \pm 19.47$ \\
\hline & Treated & $167.2 \pm 4.50$ & $\begin{array}{l}120.2 \pm 12.20 \\
*\end{array}$ & $\begin{array}{l}93.4 \pm 6.18 \\
*\end{array}$ & $91 \pm 5.8 *$ & $94 \pm 9.08 *$ & $80.2 \pm 3.43 *$ \\
\hline \multirow[t]{2}{*}{$\operatorname{AIP}(I U / L)$} & Control & $3.9 \pm 0.13$ & $2.84 \pm 0.22$ & $2.84 \pm 0.18$ & $3.9 \pm 0.25$ & $3.22 \pm 0.29$ & $4.12 \pm 0.25$ \\
\hline & Treated & $4.14 \pm 0.49$ & $2.48 \pm 0.05$ & $2.88 \pm 0.24$ & $3.72 \pm 0.27$ & $3.46 \pm 0.28$ & $4.1 \pm 0.46$ \\
\hline \multirow[t]{2}{*}{ Urea(mg/dl) } & Control & $1.42 \pm 0.17$ & $1.14 \pm 0.13$ & $1.14 \pm 0.13$ & $1.1 \pm 0.07$ & $0.62 \pm 0.11$ & $0.62 \pm 0.11$ \\
\hline & Treated & $1.22 \pm 0.19$ & $0.82 \pm 0.19 *$ & $\begin{array}{l}0.94 \pm 0.17 \\
*\end{array}$ & $0.9 \pm 0.18 *$ & $0.62 \pm 0.11$ & $0.62 \pm 0.11$ \\
\hline \multirow[t]{2}{*}{ Creatinine $(\mathrm{mg} / \mathrm{dl})$} & Control & $0.97 \pm 0.03$ & $1.3 \pm 0.28$ & $1.8 \pm 0.2$ & $1.6 \pm 0.10$ & $1.84 \pm 0.10$ & $0.72 \pm 0.04$ \\
\hline & Treated & $1.14 \pm 0.04 *$ & $1.28 \pm 0.09$ & $\begin{array}{l}1.36 \pm 0.26 \\
*\end{array}$ & $1.3 \pm 0.23$ & $1.54 \pm 0.21 *$ & $0.76 \pm 0.04$ \\
\hline
\end{tabular}

\section{DISCUSSION}

In the digestive system of the newborn calves, the digestive tracts are sterile in the womb of their mothers. Upon birth, this alimentary tract is naturally colonized by a certain of microorganisms from the environment (Savage, 1987). Under normal conditions, useful micro-organisms colonize in the rumen and lower part of intestine in a synbiotic relationship with the host.

Due to the intensive rearing and systems of calves, make them very susceptible to enteric bacterial imbalance. Pediococcus is a G+ve bacteria that belongs to a group of homofermentative lactic acid bacteria (LAB).It is the bestknown major member of probiotic bacteria (Gibson and Fuller, 2000; Rolfe, 2000), which can prevent harmful pathogens from affecting the gastrointestinal mucosa (Rinkinen et al., 2003;
Duggan et al., 2002) and provoke immune reaction (Ouwehand et al., 2003 ;Vinderola et al., 2005).

The present study showed a significant increase in body weight and body gain in 2nd, 3rd and 5th month post treatment in treated groups compared with the control group, while there was no significant change in feed intake of all groups. (Table 1).

The obtained data was in agreement with that of Dimova et al. (2013) who stated that there was no difference in feed intake. Calves fed with probiotic were healthier than control calves. In addition, probiotic had positive effec $t$ on average daily gain in calves.

The obtained results showed a significant increase in total erythrocyte count in hemoglobin content in 1st, 2nd, 3rd, 4th 
and 5th month post treatment in treated groups compared to the control one.

Also a significant increase in total protein in 1st, 3rd and 4th month in treated groups compared to control group

Our results agreed with Cetin et al. (2005) who observed that the probiotics supplementation caused statistically significant increase in the erythrocyte count and hemoglobin concentration of Turkeys.

But on the other side, Dimova et al. (2013) concluded that the hematology parameters were normal in experimental and control groups of White and Black breed with also a no significant change in total protein.

Moreover there is a significant increase in mean corpuscular hemoglobin in 1st, 2 nd, 3rd and 4th month of the treated group compared to control groups (Table2).

\section{REFERENCES}

Aattour N, Bouras M, Tome D, Marcos A, Lemonnier D (2002). Oral ingestion of Lactic acid bacteria by rats increases lymphocyte proliferation and interferon production. Br. J. 87:367-373.

Antunovic Z, Speranda M, Liker B, Seric V, Sencic D, Domacinovic M, Speranda $T$ (2005) Influence of feeding the probiotic Pioneer PDFM国 to growing lambs on performances and blood composition. Acta Vet (Beograd) 55: 287-300.

Ceslovas J, Vijilijus J, Almantas S (2005) The effect of probiotic and phytobiotics on meat properties and qualities in pigs. J Veterinary Zootech 29: 80-84.

Cetin, N,BK Guclu and E Cetin (2005): The effect of probiotic and mannanoligosaccharide on some hematological and immunological parameters in turkeys.J.VetMed SerA, 52:268-267.

Coles, E.H. (1986): Veterinary clinical pathology. $4^{\text {th }}$ edition W.B. sanders company, Philadelphia : 17-19.

Dimova, N., Baltadjieva, M., Karabashev, V., Laleva, S., Popova, Y., Slavova, P.\& Kalaydjiev, G. (2013). Effect of supplementation of probiotic zoovit in diets of calves of milk breed. Bulg. J. agric. Sci, 19, 94-97.

Doumas b. And biggs, h. (1972): Determination of serum globulin in standard methods of clinical chemistry vol .7 edited by cooper. newyork, academic press.

Doumas, b (1975): Colometric determination of total protein in serum or plasma. clin. Chem ,21:(8),249-254.

Fuller R (1989). Probiotics in man and animals. J. Appl. Bacteriol. 66,365-378.

Fuller R (1992). Probiotics: the scientific basis. Ed. Fuller R London; Champman and Hall.

G. S. Ghadban (2002). Probiotics in broiler production. Probiotika in der Broilerfu"tterung - eine bersicht. 66, $49-58$.

Garvie E I (1986) Genus Pediococcus claussen 1903. In Bergey's Manual of Systemic Bacteriology, Sneath PHA, Mair M E, Sharpe M E, Holt J G (eds), (Volume 2) pp 1075-1079. Baltimore, USA: The Williams \& Wilkins Company.

Gibson GR, Fuller R. Aspects of in vitro and in vivo research approaches directed toward identifying probiotics and prebiotics for human use. J Nutr, 2000;130: 391S-395S.

Gorgulu, M., Siuta, A., Ongel, E., Yurtseven, S., Kutlu, H.B., 2003. Effect of probiotic on growing performance and health of calves. Pak. J. Biol. Sci. 6, 651-654
The significant increase in total leucocyte count in treated groups compared to the control one at 2 nd, 3rd, 4th and 5th month was in agreement with Shaimaa, (2018) who found a significant increase in total leucocyte count in treated female calf group with Pediococcus pentosaaceus and Pediococcus acidilactici . But this result doesn't agree with Dimova et al. (2013) who stated that the level of leucocytes in the experimental calf group was lower than the control.

The results recorded in Table(3): Data showed a significant decrease in Aspartate transaminase (AST), alanine transaminase (ALT) at 2nd ,3rd, 4th and 5th month in treated group compared to control one. And also showed a significant decrease in Urea at 1st, 2nd and 3rd month in treated groups compared to control one.

This data is agreed Antunovic et al. (2005) who reported that probiotic supplementation to growing lambs resulted in slight activation.

Kamra, D. N., L. C. Chaudhary, A. Neeta, R. Singh and N. N. Pathak, 2002 Growth performance, nutrient utilization, rumen fermentation and enzyme activities in calves fed on Saccharomyces cerevisiae supplemented Diet. Indian J. Anim. Sci., 72: 472-475.

Koop-Hoolihan L (2001). Prophylactic and therapeutic uses of Probiotics: $A$ Review of Journal of the American Dietetic Association. 147:747-748.

Morrill, J. L., J. M. Morrill, A. M. Feyerherm and J. F. Laster, 1995. Plasma proteins and a probiotic as ingredients in milk replacer. J. Dairy Sci., 78: 902-907.

Nurmi E, Rantala M (1973). New aspects of Salmonella infection in broiler production. Nature. P. 241, 210-211.

Ouwehand AC, Salminen S, Roberts PJ, Ovaska J, and Salminen E. Diseasedependent adhesion of lactic acid bacteria to the human intestinal mucosa. Clin Diagn Lab Immunol, 2003; 10: 643-646

Patton, C. J. and Croush, S. R. (1977): Enzymatic determination of urea. Anal. Chem, 49: 466-469.

Paulius M, Lina A, Ana Z, Andrzej G, Mnfred OL, Areta H (2006) Effect of probiotic bioplus 2B on performance of growing rabbit. Arija Zootechnica $36: 54-59$.

Perdigon G, Macais MEN, Alvarez S, Oliver G, De Ruiz-Holgado AAP (1986). Effect of perorally administered Lactobacilli on macrophage activation in mice. Infect. Immun. 53: 404-410.

Reitman, S and Frankkel S. (1957): Acolorimeteric method for the determination of serum glutamic, oxaloacetic and glutamic pyruvic ansaminases56american journal of clinical pathology; 28:(1),56-63.

Rinkinen $M$, Jalava $K$, Westermarck $E$, Salminen $S$, and Ouwehand AC. Interaction between probiotic lacti acid bacteria and canine enteric pathogens: a risk factor for intesti-nal Enterococcus faecium colonization? Vet. Microbiol, 2003; 92: 111-119.

Rosalki, S. (1993): Qualitative determination of alkaline phosphatase clinc chem ,39(4),648-652.

Savage, D.C., 1987. Microorganisms associated with epithelial surfaces and the stability of the indigenous gastrointestinal microflora. Die Nahrung 5-6,383-390.

Snedecor,G.and Cochran, W.(1981):Statical method. $7^{\text {th }}$.lowa State UNIV.press. Iowa,USA.

Yu P, Huber JT, Theurer CB, Chen KH, Nussio LG, Wu Z (1997) Effect of steam flacked or steam rolled corn with or without Aspergillus orzyae in the diet on performance of dairy cows fed during hot weather. J Dairy Sci 80 $3293-3297$. 